\title{
Możliwość przeniesienia pracownika samorządowego w trybie art. 22 ustawy o pracownikach samorządowych ${ }^{1}$
}

\begin{abstract}
The possibility of transferring a local government employee according to Article 22 of the Act on Local Government Employees: According to the author, a member of the management board of a Warsaw's district is a local government employee hired on the basis of selection. While staying on an unpaid leave due to an election for a city councillor, such person cannot apply for a transfer, according to Article 22 of the act. This provision provides for a possibility of transferring to another local government unit regarding only employees hired on official posts.
\end{abstract}

Keywords: employees, local government, Warsaw

Słowa kluczowe: $\quad$ pracownicy, samorząd terytorialny, Warszawa

Doktor nauk prawnych, adiunkt na Wydziale Prawa i Administracji Uniwersytetu Kardynała Stefana Wyszyńskiego; ekspert ds. legislacji BAS - j.waszczuk@uksw.edu.pl • https://orcid.org/0000-0002-5407-4836

\section{Przedmiot opinii}

Przedmiotem niniejszej opinii jest udzielenie odpowiedzi na następujące pytanie: czy istnieje możliwość przeniesienia pracownika samorządowego (członka zarządu dzielnicy m.st. Warszawy) będącego na urlopie bezpłatnym w związku $\mathrm{z}$ wyborem na radnego m.st. Warszawy, do pracy w innej jednostce samorządu terytorialnego w trybie art. 22 ustawy o pracownikach samorządowych?

$\mathrm{W}$ opinii zostały wykorzystane następujące akty prawne:

- ustawa z 8 marca 1990 r. o samorządzie gminnym, t.j. Dz.U. 2018, poz. 994,

- ustawa z 15 marca 2002 r. o ustroju m.st. Warszawy, t.j. Dz.U. 2018, poz. 1817; dalej: u.u.m.st.,

1 Opinia prawna dotycząca możliwości przeniesienia pracownika samorządowego $w$ trybie art. 22 ustawy o pracownikach samorzadowych sporządzona 16 stycznia 2019 r. na zlecenie posła Klubu Parlamentarnego Platforma Obywatelska - Koalicja Obywatelska; BAS-WAP 3035/18. 
- ustawa z 21 listopada 2008 r. o pracownikach samorządowych, t.j. Dz.U. 2018, poz. 1260; dalej: u.p.sam.

Należy zaznaczyć, że niniejsza opinia ma charakter abstrakcyjny, nie odnosi się do ściśle określonego stanu faktycznego ani nie może być postrzegana jako stanowisko w indywidualnej sprawie.

\section{Treść opinii}

Udzielenie odpowiedzi na postawione na wstępie pytanie wymaga odwołania się do ustawy o ustroju m.st. Warszawy, ustawy o samorządzie gminnym oraz ustawy o pracownikach samorządowych. Miasto stołeczne Warszawa jest gminą mającą status miasta na prawach powiatu (art. 1 ust. 1 u.u.m.st.). W m.st. Warszawie są obowiązkowo utworzone jednostki pomocnicze - dzielnice m.st. Warszawy (art. 5 ust. 1 u.u.m.st.). Organem stanowiącym i kontrolnym dzielnicy jest rada dzielnicy, a organem wykonawczym - zarząd dzielnicy (art. 6 u.u.m.st.). Rada dzielnicy wybiera zarząd dzielnicy, w skład którego wchodzi burmistrz dzielnicy, jego zastępca lub zastępcy oraz pozostali członkowie zarządu, jeżeli statut dzielnicy tak stanowi (art. 10 ust. 1 u.u.m.st.). W urzędzie m.st. Warszawy: burmistrz dzielnicy m.st. Warszawy, zastępca burmistrza dzielnicy m.st. Warszawy i pozostali członkowie zarządu dzielnicy m.st. Warszawy jako pracownicy samorządowi są zatrudniani na podstawie wyboru (art. 4 ust. 1 pkt 1 ppkt e u.p.sam.).

Mając na względzie to, że m.st. Warszawa jest gminą, należy wskazać, iż w stosunku do osoby, która uzyskała mandat do Rady m.st. Warszawy, znajdą zastosowanie przepisy ustawy o samorządzie gminnym. Zgodnie z art. 24a tej ustawy: 1) Z radnym nie może być nawiązywany stosunek pracy $w$ urzędzie gminy, w której radny uzyskał mandat. 2) Radny nie może pełnić funkcji kierownika gminnej jednostki organizacyjnej oraz jego zastępcy. Artykuł 24b tej ustawy stanowi, że: 1) Osoba wybrana na radnego nie może wykonywać pracy $w$ ramach stosunku pracy $w$ urzędzie gminy, w której uzyskała mandat, oraz wykonywać funkcji kierownika lub jego zastępcy w jednostce organizacyjnej tej gminy. Przed przystąpieniem do wykonywania mandatu osoba ta obowiązana jest złożyć wniosek o urlop bezpłatny $w$ terminie 7 dni od dnia ogłoszenia wyników wyborów przez właściwy organ wyborczy. 2) Radny, o którym mowa w ust. 1, otrzymuje urlop bezpłatny na okres sprawowania mandatu oraz 3 miesięcy po jego wygaśnięciu. Niezłożenie przez radnego wniosku o urlop, o którym mowa w ust. 1, jest równoznaczne ze zrzeczeniem się mandatu (art. 24b ust. 5 ustawy o samorządzie gminnym). Przepisy te stosuje się odpowiednio do radnych dzielnicy (art. 8 ust. 1 u.u.m.st.).

Biorąc pod uwagę treść przytoczonych przepisów, trzeba stwierdzić, że radny m.st. Warszawy lub dzielnicy ma zakaz wykonywania pracy w ramach stosunku pracy jedynie w urzędzie gminy, w której uzyskał mandat, oraz nie może pełnić 
funkcji kierownika lub jego zastępcy w jednostce organizacyjnej tej gminy. Nie oznacza to, że w ogóle nie może podejmować pracy, a w konsekwencji należy uznać, iż może znaleźć zastosowanie art. 22 u.p.sam. Przepis ten stanowi, że: 1. Pracownika samorzadowego zatrudnionego na stanowisku urzędniczym, $w$ tym kierowniczym stanowisku urzędniczym, można na jego wniosek lub za jego zgoda przenieść do pracy w innej jednostce, o której mowa w art. 2, w tej samej lub innej miejscowości, w każdym czasie, jeżeli nie narusza to ważnego interesu jednostki, która dotychczas zatrudniała pracownika samorzadowego, oraz przemawiaja za tym ważne potrzeby po stronie jednostki przejmujacej. 2. Przeniesienia dokonuje się $w$ drodze porozumienia pracodawców. 3. W przypadku przeniesienia pracownika samorzadowego zatrudnionego na stanowisku urzędniczym, w tym kierowniczym stanowisku urzędniczym, do innej jednostki jego akta osobowe wraz z pozostała dokumentacja w sprawach zwiazanych ze stosunkiem pracy przekazuje się do jednostki, w której pracownik ma być zatrudniony.

Udzielenie odpowiedzi na postawione na wstępie pytanie wymaga rozstrzygnięcia, czy członek zarządu dzielnicy m.st. Warszawy, który jest zatrudniony jako pracownik samorządowy na podstawie wyboru, może być uznany za pracownika samorządowego zatrudnionego na stanowisku urzędniczym, w tym kierowniczym stanowisku urzędniczym. Zgodnie z ogólnym podziałem stanowisk pracy $\mathrm{w}$ samorządzie terytorialnym, zamieszczonym $\mathrm{w}$ art. 4 ust. 2 u.p.sam., pracownicy samorządowi są zatrudniani na stanowiskach: urzędniczych oraz stanowiskach pomocniczych i obsługi. W literaturze wskazuje się, że: [c] hoć z ustawy o pracownikach samorzadowych wynika jednoznacznie, że zawarte wniej wyliczenie kategorii stanowisk pracy ma charakter zamknięty, istnieja stanowiska, których nie da się zakwalifikować do żadnej z tych kategorii. [...] nie sa to stanowiska marginalne czy występujace w samorzadzie incydentalnie. Dotyczy to bowiem pracowników zatrudnionych: na podstawie wyboru (np. wójta), na podstawie powołania (skarbnika i zastępcy wójta). [...] Wspomnianych stanowisk nie da się zaliczyć do kategorii stanowisk urzędniczych, gdyż: nabór na wolne stanowiska urzędnicze ma charakter otwarty i konkurencyjny, tymczasem, zatrudnianie na wspomnianych stanowiskach odbywa się bez procedury naboru; w stosunku do tej grupy pracowników nie obowiązuja inne przepisy dotyczące urzędników, tj. art. 27 regulujący oceny okresowe oraz art. 31 i 32 wprowadzające obowiąek złożenia oświadczenia o prowadzonej działalności gospodarczej, a na wniosek oświadczenia majątkowego dla pracowników na stanowiskach urzędniczych. Z powyższego wynika, że podział przyjęty $w$ art. 4 ust. 2 ustawy powinien zostać przez ustawodawce uzupetniony o odrębna grupę stanowisk, tj. pracowników $z$ wyboru i powołania. Taki podział zastosowano zreszta faktycznie w rozporzadzeniu w sprawie wynagradzania pracowników samorządowych, w którym to stanowiska obejmowane na podstawie wyboru i mianowania zostały wymienione odrębnie ${ }^{2}$. Powyższe stanowisko znajduje

2 A. Piskorz-Ryń, Kategorie stanowisk pracy w samorządzie terytorialnym, 2011, Legalis. 
także uzasadnienie w świetle zróżnicowanych wymogów, które muszą spełniać pracownicy samorządowi zatrudnieni na podstawie wyboru lub mianowania oraz pracownicy samorządowi zatrudnieni na stanowiskach urzędniczych czy też kierowniczych stanowiskach urzędniczych. Zgodnie z art. 6 ust. 1 u.p.sam.: Pracownikiem samorządowym może być osoba, która: 1) jest obywatelem polskim, z zastrzeżeniem art. 11 ust. 2 i 3; 2) ma pełna zdolność do czynności prawnych oraz korzysta z pełni praw publicznych; 3) posiada kwalifikacje zawodowe wymagane do wykonywania pracy na określonym stanowisku. W myśl ust. 2 tego przepisu: Pracownikiem samorzadowym zatrudnionym na podstawie wyboru lub powołania może być osoba, która spełnia wymagania określone $w$ ust. 1 oraz nie była skazana prawomocnym wyrokiem sądu za umyślne przestępstwo ścigane z oskarżenia publicznego lub umyślne przestępstwo skarbowe. Pracownikiem samorządowym zatrudnionym na podstawie umowy o pracę na stanowisku urzędniczym: może być osoba, która spetnia wymagania określone w ust. 1 oraz dodatkowo: 1) posiada co najmniej wykształcenie średnie lub średnie branżowe; 2) nie była skazana prawomocnym wyrokiem sądu za umyślne przestępstwo ścigane z oskarżenia publicznego lub umyślne przestępstwo skarbowe; 3) cieszy się nieposzlakowana opinia (art. 6 ust. 3 u.p.sam.). Z kolei: Pracownikiem samorzadowym zatrudnionym na podstawie umowy o prace na kierowniczym stanowisku urzędniczym może być osoba, która spełnia wymagania określone w ust. 1 i ust. 3 pkt 2 i 3 oraz dodatkowo: 1) posiada co najmniej trzyletni staż pracy lub wykonywała przez co najmniej 3 lata działalność gospodarcza o charakterze zgodnym z wymaganiami na danym stanowisku; 2) posiada wykształcenie wyższe pierwszego lub drugiego stopnia w rozumieniu przepisów o szkolnictwie wyższym (art. 6 ust. 4 u.p.sam.). Należy również podkreślić, iż zatrudnienie pracownika na stanowisku urzędniczym następuje wyłącznie na podstawie otwartego i konkurencyjnego naboru, chyba że zachodzą okoliczności wyłączające ten obowiązek - tj. w sytuacji zastępstwa nieobecnego pracownika bądź przeniesienia pracownika (art. 11 i 12 u.p.sam.). Unormowanie zamieszczone w art. 11 ust. 1 u.p.sam. określa zasadę otwartości i konkurencyjności naboru kandydatów na wolne stanowiska, stanowi realizację konstytucyjnej zasady równego dostępu do służby publicznej, a sama procedura naboru (składająca się z kilku etapów) kończy się wyborem najlepszych kandydatów spełniających niezbędne wymagania i wymagania dodatkowe w największym stopniu ${ }^{3}$.

W świetle przytoczonych argumentów należy uznać, że członek zarządu dzielnicy m.st. Warszawy, który jest zatrudniony jako pracownik samorządowy na podstawie wyboru, nie może być uznany za pracownika samorządowego zatrudnionego na stanowisku urzędniczym, w tym kierowniczym stanowisku urzędniczym, a w konsekwencji nie może ubiegać się o przeniesienie do pracy

3 Wyrok Wojewódzkiego Sądu Administracyjnego w Gdańsku z 11 czerwca 2015 r., sygn. akt III SA/Gd 242/15, Legalis. 
w trybie art. 22 u.p.sam. Przepis ten wyraźnie stanowi o możliwości przeniesienia wyłącznie pracownika samorządowego zatrudnionego na stanowisku urzędniczym, a zatem nie jest uprawnione stosowanie tego przepisu w drodze wykładni rozszerzającej także do innych pracowników samorządowych. Odmiennie kształtowałaby się sytuacja, gdyby osoba wybrana na radnego m.st. Warszawy czy dzielnicy była pracownikiem samorządowym zatrudnionym na stanowisku urzędniczym, w tym kierowniczym stanowisku urzędniczym - wówczas możliwe byłoby ubieganie się o przeniesienie w trybie art. 22 u.p.sam.

\section{Podsumowanie}

Reasumując, należy stwierdzić, że członek zarządu dzielnicy m.st. Warszawy jako pracownik samorządowy zatrudniony na podstawie wyboru, będący na urlopie bezpłatnym w związku z wyborem na radnego m.st. Warszawy, nie może ubiegać się o przeniesienie w trybie art. 22 u.p.sam., z uwagi na to, że przepis ten daje możliwość przeniesienia do innej jednostki samorządu terytorialnego wyłącznie pracownikom samorządowym zatrudnionym na stanowiskach urzędniczych, a członek zarządu dzielnicy m.st. Warszawy nie spełnia tego kryterium. Przyjęcie odmiennej interpretacji mogłoby prowadzić do obejścia przepisów; w szczególności - zatrudniania pracowników samorządowych na stanowiskach urzędniczych, w tym kierowniczych, bez posiadania odpowiednich kwalifikacji, o których mowa w art. 6 ust. 3 i 4 u.p.sam.

\section{Bibliografia}

Piskorz-Ryń A., Kategorie stanowisk pracy w samorządzie terytorialnym, 2011, Legalis. 